How to cite this article:

Hossain, M.B., Yeon, A. L., \& Abdul Aziz, A. S. (2020). Sovereignty, national interest and security in bilateral investment treaties of Malaysia. Journal of International Studies, 16, 39-58. https://doi.org/10.32890/jis2020.16.3

\title{
Sovereignty, National Interest and Security in Bilateral Investment Treaties of Malaysia
}

\author{
${ }^{1}$ Mohammad Belayet Hossain, ${ }^{2}$ Asmah Laili Yeon \& ${ }^{3}$ Ahmad Shamsul Abd Aziz \\ ${ }^{1}$ School of Law, Chittagong Independent University, Bangladesh \\ ${ }^{2 \& 3}$ School of Law, Universiti Utara Malaysia, Malaysia \\ ${ }^{2}$ Corresponding author: asmah485@uum.edu.my
}

Received: 11/12/2020Ｒevised: 21/5/2020Ａccepted: 10/6/2020 Published: 30/12/2020

\begin{abstract}
The bilateral investment treaties (BITs) have continued to play a significant role in regulating foreign direct investments (FDI) in many countries. Member countries of the World Trade Organization (WTO), including Malaysia, have signed BITs to facilitate trade among nations. Malaysia's FDI laws and BITs were established to protect foreign investors, however, neither legislation had provided specific provisions on the protection of sovereignty, national interest and security. This study was conducted to address the question; to what extent are sovereignty, national interest and security protected through BITs upon the introduction of FDI into Malaysia? This study employed a non-doctrinal socio-legal research methodology, whereby the authors analyzed 15 BITs between Malaysia and other countries to explore the provisions that pertains to the protection of sovereignty, national interest and security in Malaysia. The findings conclude that the existing Malaysian BITs contain provisions to promote and protect foreign investments, however, lacked the necessary provisions on the protection of sovereignty, national interest and security. Therefore, the government should reconsider these important factors when signing future BITs.
\end{abstract}

Keywords: Bilateral Investment Treaties, Sovereignty, National Interest and Security, FDI, Malaysia.

\section{Introduction}

Bilateral investment treaties (BITs) are a mutual agreement, between two capital importing and exporting countries, that regulate foreign investments in the host country. 
The main objective of BITs is to safeguard foreign investments against nationalisation or expropriation. In the event that investments are subjected to nationalisation or expropriation, foreign investors could obtain compensation as per the international minimum standard (Driemeier, 2003). Apart from the international minimum standard, national treatment can also be bestowed to foreign investors, and is defined as a principle where a host country grants favourable treatment to foreign investors that is similar to the treatment extended to domestic investors that are in similar circumstances. In relation to the individual investments concerned, the negotiators of both countries could determine the terms and conditions of the BITs agreement. Although there are many BITs that have been signed between the same countries, each treaty have established different terms and conditions that pertains to their investment obligations (Hossain \& Rahi 2019).

Section 2(1)(b) of the FPIA 1980 of Bangladesh defines foreign investment as -

'Investment of foreign capital by a person who is not a citizen of Bangladesh or by a company incorporated outside Bangladesh, but does not include investment by a foreign Government or an agency of foreign Government' (Kituyi, 2018).

In addition, Section 2 of the Russian Law on Foreign Investments 1999 defines foreign investment as -

'The investment of foreign capital in an object of entrepreneurial activity in the territory of the Russian Federation in the form of objects under the civil law owned by the foreign investor, unless trading in such objects under the civil law is prohibited, or limited in the Russian Federation under federal laws' (Qureshi, 2002).

When a BIT has been endorsed, it will be applicable to all nationals and companies in both countries, under the local foreign direct investment (FDI) laws or policies (if any). As BITs are mainly created through the negotiations between two countries and differs across countries, there is no global treaty to date that could regulate all the BITs in the world (Hossain \& Rahi, 2018).

Since its independence, Malaysia has signed 66 BITs with various countries around the world. Malaysia signed its first BIT with the Federal Republic of Germany in $1960 .{ }^{1}$ This study analyses the BITs agreements signed by Malaysia with 15 countries to examine the provisions that pertains to the protection of sovereignty, national interest and security.

Dunning's (1977) introduced the OLI model, which refers to ownership-specific advantages $(\mathrm{O})$, location-specific advantages $(\mathrm{L})$, and internalization of manufacturing

Agreement between the Federal Republic of Germany and the Federation of Malaya concerning the promotion and reciprocal protection of investments, available at https://investmentpolicyhubold.unctad. org/Download/TreatyFile/1365 (last visited on May 6, 2019). 
products (I). As of January 2019, the number of BITs agreements signed have grown to 2971 due to the rapid growth of multinational enterprises since the 1990s. ${ }^{2}$ Therefore, Dunning's OLI model is invalid as new factors have been established that includes policyoriented issues, exchange rate facility, openness, governance, human developments and liberalization under BITs, bilateral trade agreements (BTAs), and regional trade agreements (RTAs) (Ullah \& Inaba, 2014).

Presently, there has been inadequate or alternate indication of the effects of FDI from BITs, particularly from the perspective of developing and least-developed host nations. From the analysis of OECD data, foreign investors prefer to invest in developing countries (P. Egger \& M. Pfaffermayr, 2004). This is further supported by Busse (2010). Plummer and Cheong (2009) asserted that the ASEAN BITs agreement was affirmative, yet exhibited trivial impacts on inward foreign investments. Ullah \& Inaba (2014) suggested a negative important effect for the complete example of 34 home and 74 host countries. Mina (2012) asserted that FDI-seeking host nations made efforts to develop their organizational bodies by signing any BITs. Hallward-Driemeier found little proof of BITs encouraging FDI flow from OECD countries to the least-developed and developing states.

Blonigen and Wang (2004) contended that, within the least-developed and developing states, the issues that influenced the effectiveness of FDI differed steadily, and were not highlighted by the present OLI experimental FDI models. Chantasasawat (2010) analyzed Asian host nations of both leading FDI-making countries (e.g. Malaysia, the Republic of Korea, Singapore) and main FDI-seeking countries (e.g. Thailand, Indonesia) and found that the performance of countries hosting FDI differed significantly. Plummer and Cheong (2009), and Vogiatzoglou (2007) concluded that the effects of BITs on FDI and its provisions were insignificant from the perspective of countries that are principally FDIreceiving, as opposed to FDI-making countries. Therefore, there is a lack of supporting evidence in literature on the relationship between BITs and FDI.

'Globacolisation' is a newly invented term that combines two words: globalization and colonization (Hossain, Asmah \& Aziz, 2019). Due to globacolisation, many developing countries recognized their financial problems. Hence, these countries embrace sovereignty not only as an aspiration, but also as a segregation of asset rights within the global civilization (Blaney, 1992). The proponents of 'globacolonisation' argue that due to the inflow of FDI, there will be development of infrastructure for MNEs that will ultimately benefit the economy of the host country (Howard, 2017). In Amco v. Indonesia ICSID Case No. ARB/81/1, 1 ICSID Reports 413 (1984), the tribunal ruled that if the FDI is protected, then both economic growth and the overall interest of developing states will be protected. ${ }^{3}$ The vast achievements of the new independent economies of Taiwan, South Korea, Singapore and Hong Kong suggest that openness and balanced regulations on FDI are

\footnotetext{
2 International investment agreements, bilateral investment treaties, Investment policy hub, available at https://investmentpolicyhub.unctad.org/IIA, (last visited on Jan. 24 2019).

3 Amco v. Indonesia ICSID Case No. ARB/81/1, 1 ICSID Reports 413 (1984)
} 
more advantageous to the host country (You-han Chu, 2004). The host state could rightfully prevent the entry of foreign investments that would threaten national security, or terminate such existing foreign investments (Graham \& Krugman, 2019).

However, there are some that view the implementation of FDI as a threat to the sovereignty of the host country, and to the independent development of its social and cultural life. It is argued that foreign investors are to some extent, under the jurisdiction and influence of a comparative powerful foreign government, and are less firmly under the jurisdiction of the host government (Rueber, 1973). When disputes arises, foreign governments would use its supremacy and power to favor their MNEs against the host country, or they may use the economic power of foreign investors to meet their political end (Qu \& Green, 2018). The Marxist literature argued that the development and expansion of the capital exporting countries is necessarily conditioned upon the underdevelopment of the capital receiving countries (the periphery), as the periphery is deprived of its economic surplus through the mechanisms of imperialist exploitation (Hettne, 2015).

When major interests between multinational enterprises (MNEs) and governments are in conflict, there are evidence of various forms of direct and brutal interference by MNEs in the domestic affairs of host country (Sabatier, 2014). Moreover, effective state intervention is now assumed by many to be an integral part of a successful economic intervention (Rueschemeyer \& Evans, 1992). State intervention is required to rectify market failures. Without it, the supply of collective goods will be inadequate, and would cause negative externalities that could not be controlled and the rate of accumulation will suffer consequently. The host country is then required to undertake activities that would compensate these problems and other market failures (Stubbs, 2017). Apart from that, some studies have argued that industrialisation would not have been probable in many developing states without an actual state interference. Therefore, governments must protect and subsidise their domestic industries to rapidly develop and compete in the world markets (Amsden, 1992). Based on the reviews from multiple studies, there has been inadequate review on the factors of sovereignty, national interest and security, in relation to FDI or BITs.

The aim of this study is to examine the provisions of BITs that pertains to the protection of sovereignty, national interest and security in Malaysia. This study intends to address the following questions:

(1) Should sovereignty, national interest and security be protected during the entry of FDI into Malaysia?

(2) Do the bilateral investment treaties of Malaysia protect the sovereignty, national interest and security?

By employing the doctrinal research methodology, the authors will analyse 15 bilateral investment treaties that were signed by Malaysia with various countries. The analysis focuses on sovereignty, national interest and security factors, as well as foreign investment protections such as most-favoured nation treatment, national treatment, fair and equitable treatment, full protection and security, and dispute settlement mechanisms. 


\section{The WTO Principles and FDI}

In 1995, the World Trade Organization (WTO) was established, and replaced the General Agreement on Tariffs and Trade (GATT). The WTO provided guidelines on the regulations of FDI in member countries. However, the provisions on investment, i.e. through TRIMS Agreement, is limited among the WTO member countries. The main objective of GATT was the liberalisation of international trade, and was retained as the main objective of the WTO. The system aims to achieve the liberalisation of trade through five principles which are: (a) most-favoured nation treatment $(\mathrm{MFN})$, (b) national treatment $(\mathrm{NT})$, (c) reciprocity, (d) non-discrimination, and (e) dispute settlement mechanism (Hossein, 2018). However, in accordance to WTO principles, developing countries are liberalizing their national laws and policies on FDI, while many developed countries (who are also members of the WTO) have imposed restrictions on the flow and activities of FDI (Waldock, 1963). The various laws and policies of the developed countries have incorporated provisions for the protection of sovereignty (Rueber et al, 1973), national interest and security (Turcon, 1993).

\section{Sovereignty, National Interest and Security}

According to Article 2 of the UN Charter of Economic Rights and Duties 1974, a country is bestowed permanent sovereignty over all natural resources, economic activities, and wealth within its territory. The principle of permanent sovereignty recognises '...the right of a host state to regulate and exercise authority over, and supervise the activities of foreign investors and protect its national interest...' (Duruigbo, 2006). In Electronica Sicula S.p.A (ELSI) [1989] ICJ Reports 15, 90 case, Oda J. proffered that -

'When businesses being incorporated in one country undertake commercial
transaction through local companies of another country, they be treated as
legal entities of that country and would be subject to local laws and regulations.
Thus, foreigners may have to accept a number of restrictions in order to gain
the advantages of doing business through local companies.'

In Schmidt v Secretary of State for Home Affaires [1969] 2 Ch 149, 168, Lord Denning MR dictated that 'in common law, no alien has any right to enter the country except by leave of the Crown; and the Crown can refuse leave without giving any reason'.

Sovereignty is an inherent right of every independent country in the world. International laws recognise the sovereign supremacy of a host country to govern and regulate matters within its territory including economic sovereignty, natural resources, economic activities, wealth, foreign investment, etc. ${ }^{4}$ Moreover, these countries must uphold its sovereignty over their natural resources to ensure the development of the country and its citizens. ${ }^{5}$ According to Sornarajah (2010), a host country has the right to control the implementation of FDI, in

4 U.N. Charter of economic rights and duties 1974, art. 2 (1) \& (2).

5 G.A. Res. 1803 (XVII), U.N. Doc. A/5217 (Vol. 15), Permanent sovereignty over natural resources (Dec. 14, 1962), http://legal.un.org/avl/ha/ga1803/ga1803.html (last visited on Dec. 12, 2018) 
accordance to its right of sovereignty. Investments and assets of international investors will be regulated according to the national laws in the host country. Hence, foreign investors must agree to the regulations set by the country when committing investment capital.

Furthermore, it is observed that all BITs have constrained the sovereign rights on the practices of FDI that takes place within the host country. The exclusion of sovereignty issues in multilateral agreements could be accepted due to pacta sunt servand ${ }^{6}$, however, it is a trite law that could be governed and regulated by national or local agreements. Hence, the question then arises: does the host state lose its sovereign right to control FDI due to BITs? To answer this question, a clear understanding on the nature or type of BITs is required. For example, the United States of Americas' BITs have created the right of access and national treatment that led to a substantial corrosion of the governing space. In contrast, many BITs have created a negotiated balance between the right of controlling or governing by the host country, and the right of treatment and security given to the foreign investors (Sornarajah, 2010).

Recent BITs signed by China (China-Turkey BIT), Australia (Australia-Uruguay BIT) and Indonesia (Indonesia-Finland BIT) have included provisions to control FDI in a restrictive manner, i.e. all foreign investment proposals must go through the respective regulatory bodies. These BITs extended FDI security to 'investments specifically approved in writing' or 'made in accordance with the laws, policies and regulations' of the host country (Seid, 2002). Thus, the host country preserves the right to control FDI during its initial implementation. However, problems may arise when foreign investors interfere with the sovereignty of the host country after committing their investments through their economic or the home state's political power (Seid, 2002). A modern-day example of such interference was observed in Chile, when the Allende government was overthrown in 1973 due to the nationalisation of the copper mines that did not provide any reimbursement. The foreign countries with the help of other multinational enterprises had played a role to overthrow and replace the Allende regime with a right-wing autocracy that was more favourable to the foreign businesses (Goldberg, 1975). Additionally, another example was observed during the installation of President Sisi of Egypt, who came into power in 2014. In both examples of recent events, it was argued that foreign investors did play an implicit role through their home states to create a favourable political environment for personal gains. These events have induced fear among other host countries that a similar situation may reoccur through a powerful country like the United States (USA), for which has a history of interfering with the internal affairs of other countries (Said \& Monem, 2014).

In the case of Military and Paramilitary Activities in and against Nicaragua, Nicaragua claimed that the United States was responsible for illegal military and paramilitary events in and against the Nicaragua government. ${ }^{7}$ The USA challenged this assertion in the

6 Pacta sunt servanda means "agreements must be kept", arguably the oldest principle of international law. Without this principle, which is explicitly mentioned in many agreements, treaties would be neither binding nor enforceable.

7 Military and paramilitary activities in and against Nicaragua (Nicar. v. U.S.), Judgment, 1986 I.C.J. Rep. (June 27), available at https://www.icj-cij.org/en/case/70/judgments (last visited on May, 6, 2019). 
International Court of Justice ('ICJ') and argued that the surge of communist supremacy in Nicaragua was an issue that worried every country in the region. ${ }^{8}$ The ICJ rejected the USAs' allegations, and dictated that by assisting the Contras in their rebellion against the Nicaraguan government and by mining Nicaragua's marinas, the USA had violated international laws. ${ }^{9}$ Moreover, the ICJ asserted that, based on international law, a country should not have control over the monetary system of another country. ${ }^{10}$ The court recognised that the issue should be settled within the internal sovereignty of the country.

The judgment was favourable to the host country. Multinational enterprises that are present in the host country have usually limited control over the nation's commerce activities, particularly when there is little or no political support. Such intrusion of political control has been the main issue for many countries, and often, foreign powers have utilized multinational enterprises to dictate the course of political affairs in the host countries (Chayes, 1985). In the case of Saro-Wiwa v. Shell 226 F.3d 88 (2000), it was alleged that the oil company was complicit in the murder and torture of the Ogoni tribe in the oil-producing region of Nigeria (Boele et al, 2001). Moreover, Mobil oil was accused of allegedly supporting the suppression of secessionist movement in the oil-rich Aceh province of Indonesia (Aspinall, 2019). Talisman, a Canadian oil company, had to evacuate out of Sudan due to protests in Canada for investing in a region affected by a secessionist war that was quelled in ruthless violence by the government (Foster, 2013). These real-life cases share a similar pattern that points to dictatorial governments in resource-rich host states, supported by foreign investors or foreign powers that seek exploitation of natural resources by interfering in the sovereignty of the nation.

Hence, many countries such as Vietnam, view FDI as a threat to sovereignty and autonomous growth of its societal and traditional life (Hien \& Hao, 2018). Therefore, Vietnam enacted the Law on Enterprises 2014 (LOE) and Law on Investment 2014 (LOI) that aim to control and regulate both local and foreign investors, and operations of companies and foreign-led investment projects. Similar to many other countries, the Vietnam government has placed various conditions on sensitive sectors by restricting investments. To invest in these sectors, any investment projects must fulfil the following criteria; the need of state defence and security, social ethics and community health, social order, and safety. In addition, the LOI 2014 contains an inclusive list of 267 restricted sectors, as listed in Annex 4. ${ }^{11}$

National treatment typically extends to the post-entry treatment of foreign investors. However, some BITs and other international investment treaties (IIAs) have extended the governing policy to pre-entry situations. This raised issues on the proper limits of national treatment, such that an extension is normally accompanied by a 'negative list' of excepted areas of investment activity, whereby national treatment does not apply or a 'positive list'

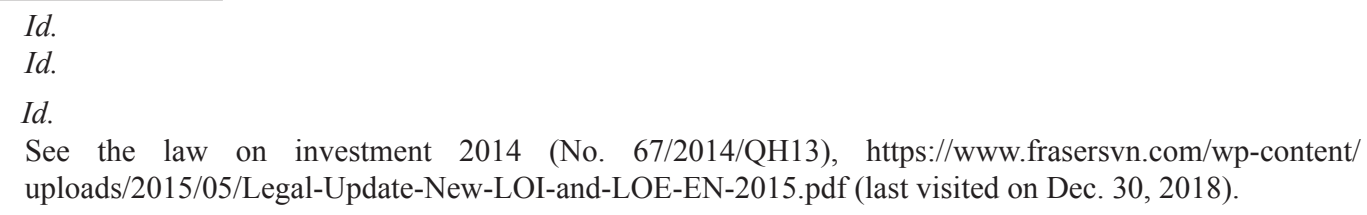
uploads/2015/05/Legal-Update-New-LOI-and-LOE-EN-2015.pdf (last visited on Dec. 30, 2018). 
of areas of investment activity, whereby national treatment is granted. In addition, several types of general exceptions to national treatment exist that relates to public health, safety and morals, and national security. Albeit, these are not included in all agreements, particularly in BITs. There are many developed host countries that have sanctioned specific areas of industries that are restricted to foreign influence and investments due to reason concerning national interest and security. For example, the purchasing of shares by Chinese National Oil Company ("CNOC") in Unocal (Petrusic, 2005); bid for the purchasing of shares by the Gulf states' in companies running American ports (Hanieh, 2016); purchasing of shares by a Chinese state oil company in an Australian company (Lai et al, 2015); and the Rio Tinto bid that was opposed on grounds of national security (Vivoda \& G. Graetz, 2017). The notion of 'national security' is used as a valid excuse to avoid FDI in many sensitive sectors such as the defence industries, technology based industries, and coastal shipping.

Many BITs do include national security as an exemption within its provisions, and allow the host country to decline the permit for FDI entry even if such treaty provides pre-entry national treatment. Additionally, this exception allows the host countries to refuse further implementation of FDI after entry if national security is threatened, including eliminating foreign investments when conditions of the treaty are violated (Subedi, 2017). For example, the USA applies both sector-specific review systems and national security to the FDI. According to the Exon-Florio statute, ${ }^{12}$ in the context of national security, the President of the USA or Committee on Foreign Investment in the United States (CFIUS) has the authority to restrict or enforce remedial actions on FDI. Other countries such as Australia [the Foreign Acquisitions and Takeovers Regulation 2015, s. 22(2)], Canada (the Investment Canada Act, RSC 1985, § 4), European Union [article 65(1)(b) of the Treaty on the Functioning of the European Union ("TFEU")], United Kingdom (section 13 of the UK Industry Act 1975), China (article 2 of the National Security Law of the People's Republic of China) and Russia (article 6 of the Strategic Investments Law 2017) have established specific provisions to safeguard their national interest and security before the implementation of FDI at its entry level. ${ }^{13}$

\section{Malaysian BITs with Different Countries ${ }^{14}$}

\section{(a) Austria}

The Government of Malaysia signed a BIT with the Republic of Austria in 1985 that remains enforced till today. The Preamble of the BIT aims at creating favourable conditions for a greater economic cooperation, and recognises the promotion and reciprocal protection of investments. The BIT includes fair and equitable treatment, full protection, most-favoured nation treatment, national treatment, and various other benefits for investors. Articles 9 and

12 The Exon-Florio amendment to the Defense Production Act of 1950, as amended by the Foreign Investment and National Security Act of 2007, 50 U.S.C. $§ 4565$.

13 Investment policy hub, UNCTAD, Investment laws, available at https://investmentpolicyhubold.unctad. org/InvestmentLaws (last visited on May 22, 2019).

14 Id. 
10 of the BIT contains provisions on the settlement of disputes between the Contracting Parties or any of its investors. Generally, many BITs would allow countries to include their commitment via positive list or negative list. General exception clauses could be added in the provisions of BITs that would protect sovereignty, national interest and security, in the form of Art. XX and XXI of GATT. However, the BIT does not provide any reference to sovereignty, national interest and security. ${ }^{15}$

\section{(b) Belgo-Luxembourg Economic Union}

The Government of Malaysia signed a BIT with the Belgo-Luxembourg Economic Union (BLEU) at Kuala Lumpur in 1979, and remains enforced till today. The Preamble of the BIT aims at creating favorable conditions for greater economic cooperation and recognizes the encouragement and reciprocal protection of investments. The BIT includes fair and equitable treatment, full protection, most-favored nation treatment, national treatment under international law, and various other benefits for investors. Articles 10 and 11 of the BIT includes provisions on settlement of disputes between the Contracting Parties or any of its investors. The BIT does not provide any reference to sovereignty, national interest and security. ${ }^{16}$

\section{(c) Denmark}

The Government of Malaysia signed a BIT with the Kingdom of Denmark in 1992, and remains enforced till today. The Preamble of the BIT aims at creating favourable conditions for investments, promote greater economic cooperation, and recognize fair and equitable treatment of investment on a reciprocal basis. This BIT includes full protection and security, most-favoured nation treatment, national treatment, and various other benefits for investors. Articles 10 and 11 of the BIT includes provisions on settlement of disputes between the Contracting Parties or any of its investors. The BIT does not provide any reference to sovereignty, national interest and security. ${ }^{17}$

\section{(d) Germany}

The Government of Malaysia signed a BIT with the Federal Republic of Germany at Kuala Lumpur in 1960, and remains enforced till today. The Preamble of the BIT aims at fostering and strengthening economic cooperation, and intends to create favourable conditions for investments through contractual protection. The BIT includes most-favoured nation treatment, national treatment, and various other benefits for investors. Article 9 states

15 Agreement between the Republic of Austria and Malaysia for the promotion and protection of investments, available at https://investmentpolicyhubold.unctad.org/Download/TreatyFile/201 (last visited on Jan. 8, 2019).

16 Investment guarantee agreement between Malaysia and the Belgo-Luxemburg Union, available at https:// investmentpolicyhubold.unctad.org/Download/TreatyFile/5686 (last visited on Jan. 14, 2019).

17 Agreement between the Government of the Kingdom of Denmark and the Government of Malaysia for the mutual promotion and protection of investments, available at https://investmentpolicyhubold.unctad.org/ Download/TreatyFile/1017 (last visited on Jan. 16, 2019). 
that both countries "shall co-operate with each other in furthering the interchange and use of scientific and technical knowledge and development of training facilities particularly in the interest of increasing productivity and improving the standards of living in their territories." Protocol 9 states that both countries "shall refrain from any measures which contrary to the principles of free competition, may prevent or hinder sea-going vessels of the other Contracting Party from participating in the transport of goods that are intended for investment within the meaning of this Agreement." Article 10 of the BIT includes provisions on settlement of disputes between the Contracting Parties or any of its investors. The BIT does not provide any reference to sovereignty, national interest and security. ${ }^{18}$

\section{(e) India}

The Government of Malaysia signed a BIT with the Government of the Republic of India at Kuala Lumpur in 1995, but was terminated in 2017. The Preamble of the BIT was aimed at expanding and strengthening economic and industrial cooperation for the long term, and to create favourable conditions for investments by recognizing the need to protect such investments. The BIT included full and adequate protection and security at all times, fair and equitable treatment, most-favoured nation treatment, and various other benefits for investors. Articles 7 and 8 of the BIT contained provisions on settlement of disputes between the Contracting Parties or any of its investors. The BIT did not provide any reference to sovereignty, national interest and security. ${ }^{19}$

\section{(f) Republic of Korea}

The Federal Government of Malaysia signed a BIT with the Republic of Korea at Seoul in 1988, and remains enforced till today. The Preamble of the BIT aims at creating favourable conditions for investments and recognizes the need to promote and protect such investments. The BIT includes fair and equitable treatment, full protection and security, most-favoured nation treatment, national treatment under international law, and various other benefits for investors. With respect to investments, and returns in the banking and insurance sectors, Article 3 of the BIT states that most-favoured nation treatment and national treatment will be granted in compliance with the relevant laws and regulations of each Contracting Party. Articles 9 and 10 of the BIT include provisions on settlement of disputes between

the Contracting Parties or any of its investors. The BIT does not provide any reference to sovereignty, national interest and security. ${ }^{20}$

18 Agreement between the Federal Republic of Germany and the Federation of Malaya concerning the promotion and reciprocal protection of investments, available at https:/investmentpolicyhubold.unctad. org/Download/TreatyFile/1365 (last visited on Jan. 25, 2019).

19 Agreement between the Government of the Republic of India and the Government of Malaysia for the promotion and protection of investments, available at https://investmentpolicyhubold.unctad.org/ Download/TreatyFile/1576 (last visited on Feb. 3, 2019).

20 Agreement between the Government of the Republic of Korea and the Government of Malaysia for the promotion and protection of investments, available at https:/investmentpolicyhubold.unctad.org/ Download/TreatyFile/1806 (last visited on Mar. 16, 2019). 


\section{(g) The Netherlands}

The Government of Malaysia signed a BIT with the Government of the Kingdom of Netherlands in 1971, and remains enforced till today. The Preamble of the BIT aims to strengthen the ties of friendship, foster and promote closer economic relations, and to encourage investments on the basis of mutual benefits. According to Article 2(2) of the agreement, both countries agree to promote co-operation within the framework of their respective laws and regulations that would contribute to the improvement of the standards of living among the people. In addition, both countries would cooperate for the development of international shipping services, particularly with respect to all forms of shipping vessels (except coastal trade and fisheries) that would abide to national and most-favoured nation treatment principles (Article 4). Article 7 corresponds to the importation without payment of customs duty for goods, material and equipment for the purpose of exhibition and display, provided that these items are re-exported within the time period. The BIT includes fair and equitable treatment, most-favoured nation treatment, national treatment under international law, and other various benefits for investors. Articles 12, 13 and 15 of the BIT contain provisions on settlement of disputes between the Contracting Parties or any of its investors. Article 17(4) permits the Government of the Netherlands to terminate the present agreement upon due discretion. The BIT does not provide any reference to sovereignty, national interest and security. ${ }^{21}$

\section{(h) Romania}

The Government of Malaysia signed a BIT with the Government of the Socialist Republic of Romania at Bucharest in 1996, which replaced the first BIT signed in 1982 and has remain enforced till today. The Preamble of the BIT aims to expand and deepen economic and industrial cooperation over the long term and to create favourable conditions for investments by recognizing the need to protect these investments. The BIT includes provisions on equitable treatment at all times, full adequate protection and security, mostfavoured nation treatment, and various other benefits for investors. Articles 6 and 7 of the BIT include provisions on settlement of disputes between the Contracting Parties or any of its investors. The BIT does not provide any reference to sovereignty, national interest and security. ${ }^{22}$

\section{(i) Switzerland}

The Government of Malaysia signed a BIT with the Government of the Swiss Confederation at Kuala Lumpur in 1978, and remains enforced till today. The Preamble of the BIT aims to create favourable conditions for capital investments by recognizing the need to protect such

$21 \quad$ Agreement on economic co-operation between the Kingdom of the Netherlands and Malaysia, available at https://investmentpolicyhubold.unctad.org/Download/TreatyFile/1959 (last visited on Jan. 19, 2019).

22 Agreement between the Government of Malaysia and the Government of Romania for the promotion and reciprocal protection of investments, available at https://investmentpolicyhubold.unctad.org/Download/ TreatyFile/1962 (last visited on Feb 12, 2019). 
investments. The BIT provides protection in pursuant to local legislation, fair and equitable treatment, most-favoured nation treatment, national treatment, and various other benefits for investors. Article 9 of the BIT contains provisions on settlement of disputes between the Contracting Parties or any of its investors. The BIT does not provide any reference to sovereignty, national interest and security. ${ }^{23}$

\section{(j) Turkey}

The Government of Malaysia signed a BIT with the Government of the Republic of Turkey in 1998, and remains enforced till today. The Preamble of the BIT aims to expand and deepen economic and industrial cooperation over the long-term and create favourable conditions for investments by recognizing the need to protect such investments. The BIT provides protection and security in pursuant to the local legislation, fair and equitable treatment, most-favoured nation treatment, and various other benefits for investors. Articles 7 and 8 of the BIT include provisions on settlement of disputes between the Contracting Parties or any of its investors. The BIT does not provide any reference to sovereignty, national interest and security. ${ }^{24}$

\section{(k) United Arab Emirates}

The Government of Malaysia signed a BIT with the Government of the United Arab Emirates (UAE) at Kuala Lumpur in 1991, and remains enforced till today. The Preamble of the BIT aims to create favourable conditions for greater economic cooperation for investments by recognizing the need to protect such investments. The BIT provides protection and security in pursuant to the local legislation, fair and equitable treatment, most-favoured nation treatment, and various other benefits for investors. Articles 9 and 10 of the BIT contain provisions on settlement of disputes between the Contracting Parties or any of its investors. The BIT does not provide any reference to sovereignty, national interest and security. ${ }^{25}$

\section{(l) United Kingdom}

The Government of Malaysia signed a BIT with the Government of the United Kingdom of Great Britain and Northern Ireland (UK) at London in 1981, and remains enforced till today. The Preamble of the BIT aims to create favourable conditions for investment by recognising the need to protect these investments under an international agreement. The BIT provides protection and security in pursuant to the local legislation, fair and equitable

23 Agreement between the Government of the Swiss Confederation and the Government of Malaysia concerning the promotion and reciprocal protection of investments, available at https:/investmentpolicyhubold.unctad. org/Download/TreatyFile/4823 (last visited on Dec. 16, 2018).

24 Agreement between the Government of the Republic of Turkey and the Government of Malaysia for the reciprocal promotion and protection of investments, available at https:/investmentpolicyhubold.unctad.org/ Download/TreatyFile/1970 (last visited on Nov. 28, 2018).

25 Agreement between the Government of the United Arab Emirates and the Government of Malaysia for the promotion and protection of investments, available at https://investmentpolicyhubold.unctad.org/ Download/TreatyFile/1971 (last visited on Jan. 13, 2019). 
treatment, most-favoured nation treatment, national treatment, and various other benefits for investors. Articles 7 and 8 of the BIT contain provisions on settlement of disputes between the Contracting Parties or any of its investors. The BIT does not provide any reference to sovereignty, national interest and security. ${ }^{26}$

\section{(m) Uzbekistan}

The Government of Malaysia signed a BIT with the Government of the Republic of Uzbekistan at Kuala Lumpur in 1997, and remains enforced till today. The Preamble of the BIT aims to expand and strengthen economic and industrial cooperation over the longterm, and create favourable conditions for investments by recognizing the need to protect such investments. The BIT provides protection and security in pursuant to the local laws, regulations and national policies. The agreement also includes equitable treatment, mostfavoured nation treatment, and various other benefits for investors. Articles 7 and 8 of the BIT include provisions on settlement of disputes between the Contracting Parties or any of its investors. The BIT does not provide any reference to sovereignty, national interest and security. ${ }^{27}$

\section{(n) Vietnam}

The Government of Malaysia signed a BIT with the Government of the Socialist Republic of Vietnam at Kuala Lumpur in 1992, and remains enforced till today. The Preamble of the BIT aims to expand and deepen economic and industrial cooperation over the longterm, and create favourable conditions for investments by recognizing the need to protect such investments. The BIT provides protection and security in pursuant to the local laws, regulations and administrative practices. The agreement also includes fair and equitable treatment, most-favoured nation treatment, and various other benefits for investors. Articles 7 and 8 of the BIT include provisions on settlement of disputes between the Contracting Parties or any of its investors. The BIT does not provide any reference to sovereignty, national interest and security. ${ }^{28}$

\section{(o) Bangladesh}

The People's Republic of Bangladesh signed a BIT with the Government of Malaysia at Kuala Lumpur in 1994, and remains enforced till today. The Preamble of the BIT aims to expand and strengthen economic and industrial cooperation over the long-term, and create

\footnotetext{
26 Agreement between the Government of the United Kingdom of Great Britain and Northern Ireland and the Government of Malaysia, available at https://investmentpolicyhubold.unctad.org/Download/ TreatyFile/1972 (last visited on Feb. 15, 2019).

27 Agreement between the Government of Malaysia and the Government of the Republic of Uzbekistan for the promotion and reciprocal protection of investments, available at https://investmentpolicyhubold.unctad. org/Download/TreatyFile/5691 (last visited on Dec. 13, 2018).

28 Agreement between the Government of the Socialist Republic of Vietnam and the Government of Malaysia for the promotion and protection of investments, available at https://investmentpolicyhubold.unctad.org/ Download/TreatyFile/1974 (last visited on Jan. 16, 2019).
} 
favourable conditions for investments by recognising the need to protect such investments. The BIT provides protection and security in pursuant to local laws, regulations and national policies. The agreement also includes equitable treatment, most-favoured nation treatment, and various other benefits for investors. Articles 6 and 7 of the BIT include provisions on settlement of disputes between the Contracting Parties or any of its investors. The BIT does not provide any reference to sovereignty, national interest and security. ${ }^{29}$

Table 1 summarizes the provisions of the BITs signed by Malaysia with 15 countries:

Table 1

Malaysian BITs with different countries

\begin{tabular}{|c|c|c|c|c|}
\hline Country & $\begin{array}{l}\text { Signing date } \& \\
\text { present status }\end{array}$ & $\begin{array}{l}\text { Sovereignty, national } \\
\text { interest and security }\end{array}$ & FDI protections & $\begin{array}{c}\text { Dispute } \\
\text { settlement } \\
\text { provisions }\end{array}$ \\
\hline Austria & $\begin{array}{l}22 / 12 / 2000 \\
\text { In force }\end{array}$ & No & NT, MFN, FET & Yes \\
\hline BLEU & $\begin{array}{l}\text { 22/05/1981 } \\
\text { In force }\end{array}$ & No & NT, MFN, FET & Yes \\
\hline Denmark & $\begin{array}{l}\text { 05/11/2009 } \\
\text { In force }\end{array}$ & No & NT, MFN, FET & Yes \\
\hline Germany & $\begin{array}{l}\text { 06/05/1981 } \\
\text { In force }\end{array}$ & No & NT, MFN & Yes \\
\hline India & $\begin{array}{l}\text { 09/02/2009 } \\
\text { In force }\end{array}$ & No & MFN, FET & Yes \\
\hline Korea & $\begin{array}{c}\text { 21/06/1999 } \\
\text { Signed }\end{array}$ & No & NT, MFN, FET & Yes \\
\hline Netherlands & $\begin{array}{l}\text { 01/11/1994 } \\
\text { In force }\end{array}$ & No & NT, MFN, FET & Yes \\
\hline Romania & $\begin{array}{l}\text { 13/03/1987 } \\
\text { In force }\end{array}$ & No & MFN, FET & Yes \\
\hline Switzerland & $\begin{array}{l}\text { 14/10/2000 } \\
\text { In force }\end{array}$ & No & NT, MFN, FET & Yes \\
\hline Turkey & $\begin{array}{c}\text { 12/04/2012 } \\
\text { Signed }\end{array}$ & No & MFN, FET & Yes \\
\hline UAE & $\begin{array}{c}\text { 17/01/2011 } \\
\text { Signed }\end{array}$ & No & MFN, FET & Yes \\
\hline UK & $\begin{array}{l}\text { 19/06/1980 } \\
\text { In force }\end{array}$ & No & NT, MFN, FET & Yes \\
\hline
\end{tabular}

29 $\quad$ Agreement between the Government of Malaysia and the Government of the People's Republic of Bangladesh for the promotion and protection of investments, available at https://investmentpolicyhubold. unctad.org/Download/TreatyFile/5126 (last visited on Nov. 17, 2019). 


\begin{tabular}{ccccc}
\hline Country & $\begin{array}{c}\text { Signing date \& } \\
\text { present status }\end{array}$ & $\begin{array}{c}\text { Sovereignty, national } \\
\text { interest and security }\end{array}$ & FDI protections & $\begin{array}{c}\text { Dispute } \\
\text { settlement } \\
\text { provisions }\end{array}$ \\
\hline Uzbekistan & $\begin{array}{c}18 / 07 / 2000 \\
\text { In force } \\
\text { Vietnam }\end{array}$ & No & MFN, FET & Yes \\
Signed & No & MFN, FET & Yes \\
Bangladesh & $\begin{array}{c}20 / 10 / 1994 \\
\text { In force }\end{array}$ & No & MFN, FET & Yes \\
\hline
\end{tabular}

Source: Compiled by the authors. NT=National treatment; MFN=Most-favored nation treatment; FET=Fair and equitable treatment

\section{Findings and Recommendations}

Based on the results from Table 1 and the discussion on the provisions of BITs signed by the Malaysian government with 15 countries, this study asserts that no references were made for the protection of sovereignty, national interest and security. All BITs that were signed contained provisions on dispute settlement mechanisms, with some BITs included provisions on environment, human labour rights and sustainable development. Moreover, every BIT contained specific provisions for full and adequate protection and security, fair and equitable treatment, most-favoured nation treatment, national treatment, compensation for expropriation and nationalization, and various other benefits for investors.

China's 'Belt and Road Initiative' would likely diversify into other sectors in Malaysia, away from its current focus on infrastructure and property development projects (Hew, 2018). This has raised concern over 'Malaysia sovereignty', caused mainly by the influx of Chinese investments. ${ }^{30}$ For example, due to a large real estate development by a Chinese firm in Forest City, Johor, the demographic around that area has changed. This massive development will damage the longstanding fishing industry, the mangrove forests, and a Ramsar Site protected for the conservation of its wetlands in the area. Furthermore, it will damage the local property market of Malaysia (Leng, 2018). In most cases, foreign investors or MNEs would associate with the inner circle of economic elites. In most cases, the actions of privatisation by local governments have led to allegations of corruption (Gomez \& Jomo, 1999).

30 It should be noted that the ASEAN-China and ASEAN-Hong Kong-China FTA do not provide any reference for the protection of sovereignty in Malaysia. See Agreement on investment of the framework agreement on comprehensive economic co-operation between the People's Republic of China and the Association of Southeast Asian Nations, available at https://investmentpolicyhubold.unctad.org/Download/ TreatyFile/2596 (last visited on Dec. 12, 2018); and Agreement on investment among the Governments of the Hong Kong Special Administrative Region of the People's Republic of China and the member states of the Association of Southeast Asian Nations, available at https://investmentpolicyhubold.unctad.org/ Download/TreatyFile/5655, (last visited on Dec. 12, 2018). 
These conditions would essentially lead to large volatility in the economy. Malaysia intended to address this issue through its constitution, i.e. to provide an opportunity to the majority of Malay citizens so that they obtain a percentage share in the economic development. However, this action is considered discriminatory as it would be difficult to uphold the national treatment principles of WTO for foreign investors, when the domestic law itself is prejudiced (i.e. the ethnic Chinese and Indians who are Malaysian citizens) (Gomez \& Jomo, 1999).

The other concern of sovereignty is on foreign land and real property ownership in Malaysia, and is governed by Section 433B of the National Land Code (Amendment) Act 2016. In accordance with the Act, the state governments and their agencies have the authority to deal with the issue, and should exercise this right in the general interest of their citizens. However, corruption by government officials has become a growing threat to sovereignty (Aw \& Tang, 2017). Corruption can be stopped if laws are enforced and executed to ensure that land and property ownership are not undermined. Simply put, corruption has become a hindrance that has resulted in the inconsistencies of policy implementation. These policies have not only incurred economic cost for lower income home buyers, but has created multiple legal loopholes and red tapes for corruption (Hau, 2018). Moreover, the implementation of FDI can be hindered due to internal corruption, or when a new government replaces a corrupted one (Beh, 2011).

The Malaysian Investment Development Authority (MIDA) Act 1965 allows FDI to be implemented in the manufacturing and service sectors, however, does not provide any specific provision that authorizes the governing body to consider national interest and security when prohibiting or restricting any FDI proposals at its entry level. ${ }^{31}$ According to Section 4A of the Promotion of Investments Act (PIA) 1986, the Minister is required to consider "any activity or product which is of national and strategic importance to Malaysia on a case-to-case basis". Section 4 enables the Minister to determine the promoted activities and products, while Section 4(3) provides a 'consideration list' for the Minister to take into account, upon his discretion. ${ }^{32}$ Therefore, the present provisions provide the opportunity for political bias and corruption when determining the promoted activities or products (Ping, 2017).

The Industrial Coordination Act (ICA) 1975 dictates that a license is required for manufacturing products. Before the issuance of the license, the license officer will consider the national, economic and social objectives. ${ }^{33}$ Section 4(4) permits the officers to impose such conditions at their discretion. In the MIDA Act, PIA and ICA, no review is required, and is generally "permitted for the revocation of licenses, as the conferment of which

31 Malaysian Investment Development Authority (MIDA), General Guidelines \& Facilities, available at http://www.mida.gov.my/home/general-guidelines-\&-facilities/posts/ (last visited on Jan. 1, 2019).

32 Attorney Generals Chamber of Malaysia, Laws of Malaysia, http://www.agc.gov.my/agcportal/uploads/ files/Publications/LOM/EN/Act\%20327.pdf. (last visited on Jan. 1, 2019).

33 Industrial Coordination Act 1975, available at http://grp.miti.gov.my/miti-grp/resources/Public\%20Consultation/Industrial_Coordination_Act_1975_Act_156.pdf, (last visited on Jan. 1, 2019). 
is entirely at the discretion of the state". ${ }^{34}$ Consequently, there has been allegations of corruption by license officers that have taken bribes by imposing strict conditions to be fulfilled by manufacturers, or for other reasons not identified. ${ }^{35}$ These corruptions have impeded economic development in Malaysia (Shamsuddin et al, 2017). In 2018, a total of 894 people were arrested that included public officials, top management and supporting staff by the Malaysian Anti-Corruption Commission (MACC) for alleged corruption. ${ }^{36}$ The BITs signed by Malaysia made no reference to national interest and security during the initial approval of foreign investments at its entry level. ${ }^{37}$

Based on the discussions and findings of this study, alike many other developing countries, Malaysia FDI laws and BITs do not provide any specific reference or established the relevant provisions for the protection of its sovereignty, national interest and security. As the existing FDI laws are inconsistent due to the absence of a unifying global treaty, the BITs are presently regulating the FDI laws in Malaysia. Moreover, it is suggested that the act of liberalization does not affect the influx of foreign investment in host countries. For instance, the United Nations Conference on Trade and Development (UNCTAD) Report in 1999 revealed that many African countries with liberal investment regulations had failed to attract the inflow of FDI. In contrast, since 1992, China has continued to be a major receiver of foreign investments despite being a restrictive investment regime among the developing countries. Similarly, Thailand and Vietnam have both enforced tighter regulations compared to the Latin American countries, however, have continued to receive more FDIs that the latter (Hossain, 2018).

In practice, both liberalization and restrictive regulations can have both positive and negative effects in Malaysia. Hence, it is important to ensure a more balanced BITs that would fulfill its objectives. The Malaysian government should consider inserting provisions that address the protection of sovereignty, national interest and security into BITs to protect its national interest, while simultaneously protecting the interest of foreign investors in accordance to the guidelines set by the WTO. Therefore, sustainable BITs should be sought after that strikes a balance between liberalization and restrictive regulations to ensure sustainable development of both countries.

\section{Conclusion}

The FDI laws in Malaysia contain provisions that only promotes the inflow of FDI. At the post-entry stage of its implementation, different incentives and protection are provided to

34 Murphyores Ltd v The Commonwealth 136 C.L.R. 1 (1976).

35 Malaysian Anti-Corruption Commission, corruption case - local in engineering \& construction (An investment holding II - a case study), available at

http://www.sprm.gov.my/index.php/en/enforcement/corruption-offenders-database/81-uncategorised/1357case-studies (last visited on Jan. 12019 ).

362018 annual statistics on arrest, available at https://www.sprm.gov.my/index.php/en/enforcement/statisticson-arrests?id=2587 (last visited on Jan. 18, 2019).

37 See, e.g., Malaysia-Bangladesh BIT, Malaysia-Australia BIT, Malaysia-Germany BIT, Malaysia-Denmark BIT, etc. 
foreign investors. In the absence of a multilateral treaty or specific guidelines, Malaysia regulates its FDI laws in accordance to BITs. Based on the WTO guidelines for 'reciprocity', both countries should develop BITs that ensures the interests of all parties are equally preserved, and to sustain economic relations between the countries over the long term. Moreover, it is necessary to recognize the sovereign right through legal or policy regimes and set satisfactory conditions to control FDI in selective sectors. These FDI laws should encompass provisions on national interest, social objectives and economic development that are free from manipulation and corruption. It is therefore important to create a culture that upholds fundamental human rights, freedom, the rule of law, political freedom, equality, justice, and economic and social progress that would be safeguarded for everyone in Malaysia.

\section{Acknowledgement}

This research received no specific grant from any funding agency.

\section{References}

Aly, A. M. S., \& Monem, A. (2014). Deciphering Abdel Fattah el-Sisi: President of Egypt's third republic. Crown Center for Middle East Studies, 82.

Amsden, A. (1992). A theory of government intervention in late industrialization. State and market in development: Synergy or rivalry, 53-84.

Aspinall, E. (2007). The construction of grievance. Journal of Conflict Resolution, 51(6), 950-972.

Aw, Y. T., \& Tang, T. C. (2010). The determinants of inward foreign direct investment: The case of Malaysia. International Journal of Business and Society, 11(1), 59-76.

Beh, L. (2017). Public ethics and corruption in Malaysia. In Public administration in Southeast Asia (pp. 171-191). Routledge.

Blaney, D. (1992). Equal sovereignty and an African statehood: Tragic elements in the African agenda in world affairs. Praeger.

Boele, R., Fabig, H., \& Wheeler, D. (2001). Shell, Nigeria and the Ogoni. A study in unsustainable development: I. The story of Shell, Nigeria and the Ogoni peopleenvironment, economy, relationships: conflict and prospects for resolution 1. Sustainable development, 9(2), 74-86.

Busse, M., Königer, J., \& Nunnenkamp, P. (2010). FDI promotion through bilateral investment treaties: more than a bit? Review of World Economics, 146(1), 147-177.

Chantasasawat, B., Fung, K. C., Iizaka, H., \& Siu, A. (2010). FDI flows to Latin America, East and Southeast Asia, and China: Substitutes or complements? Review of Development Economics, 14(3), 533-546.

Chayes, A. (1985). Nicaragua, the United States, and the World Court. Colum. L. Rev., 85, 1445. 
Chu, Y. (1989). State structure and economic adjustment of East Asian newly industrialised countries. International Organisation, 43, 647-72.

Dunning, J. (1977). Trade, location of economic activity and MNE: A search for an eclectic approach. The International Allocation of Economic Activity, 395-418.

Egger, P., Pfaffermayr, M. (2004). The impact of bilateral investment treaties on foreign direct investment. J. COMP. ECON. 32, 788-804.

Foster, G. K. (2013). Investors, states, and stakeholders: Power asymmetries in international investment and the stabilizing potential of investment treaties. Lewis \& Clark L. Rev., 17, 361 .

Goldberg, P. A. (1975). The politics of the Allende overthrow in Chile. Political Science Quarterly, 90(1), 93-116.

Graham, E., Krugman, P. (1991). Fdi in the United States. Wiley.

Gomez, E. T., Gomez, T., \& Jomo, K. S. (1999). Malaysia's political economy: Politics, patronage and profits. CUP Archive.

Hanieh, A. (2016). Capitalism and class in the Gulf Arab states. Springer.

Hettne, B. (1995). Development theory and the three worlds: towards an international political economy of development.

Hossain, M. B., Yeon, A. L., Aziz, A. (2019). Environmental protection and the bilateral investment treaties of Malaysia and Netherlands: A comparison. Journal of European Energy and Environmental Law Review, 5(28).

Hossain, M., Rahi, S. (2018). International economic law and policy: A comprehensive and critical analysis of the historical development. Beijing Law Review, 9, 524.

Hossain, M. B. (2018). Fleshing out the provisions for protecting foreign investment. Yustisia Jurnal Hukum, 7(3), 406-4427.

Howard, D. (2017). Creating consistency through a world investment court. Fordham International Law Journal, 41(1).

Kishoiyian, B. (1993). The utility of bilateral investment treaties in the formulation of customary international law. NW. J. INT'L L. \& BUS. 14, 327.

Lai, H., O'Hara, S., \& Wysoczanska, K. (2015). Rationale of internationalization of China's national oil companies: Seeking natural resources, strategic assets or sectoral specialization? Asia Pacific Business Review, 21(1), 77-95.

Mina, W. (2012). The institutional reforms debate and FDI flows to the MENA region: The "Best" ensemble. World Development, 40, 1798-1809.

Petrusic, M. (2005). Oil and national security: CNOOC's failed bid to purchase unocal. NCL Rev., 84, 1373.

Plummer, M., Cheong, D. (2009). FDI effects of ASEAN integration. Région et Développement, 49-67.

Qureshi, A. (2002). Perspectives in international economic law. Kluwer law international.

$\mathrm{Qu}, \mathrm{T}$., Green, M. B. (2018). Chinese foreign direct investment: A subnational perspective on location. Routledge.

Reuber, G. L. (1973). Private foreign investment in development.

Rueschemeyer, D., \& Evans, P. B. (1983). The state \& economic transformation: Towards an analysis of the conditions underlying effective intervention. Center for the Comparative Study of Development, Brown University. 
Sabatier, P. (1975). Social movements and regulatory agencies: Toward a more adequateand less pessimistic - theory of "clientele capture". Policy Sciences, 6(3), 301-342.

SEID, S. (2002). Global regulation of foreign direct investment. CRC press book.

Sornarajah, M. (2017). The international law on foreign investment. Cambridge University Press.

Stubbs, R. (2017). Rethinking Asia's economic miracle: The political economy of war, prosperity and crisis. Macmillan International Higher Education.

Subedi, S. (2008). International investment law: Reconciling policy and practice. Oxford.

Ullah, M. S., Inaba, K. (2014). Liberalization and fdi performance: Evidence from ASEAN and SAFTA member countries. Journal of Economic Structures 3(6).

Vivoda, V., \& Graetz, G. (2017). Mergers and acquisitions: The politics of megadeals in the mining industry. In Mining in the Asia-Pacific (pp. 121-138). Springer, Cham.

Vogiatzoglou, K. (2007). Vertical specialization and new determinants of fdi: Evidence from South and East Asia. Global Econ. Rev, 36, 245-66. 